\title{
A New Look at Old Books: The Collection of the Nassau Public Library in the Mid-19th Century
}

\author{
Virginia C. F. Ballance \\ The College of The Bahamas ${ }^{1}$
}

\begin{abstract}
Discovery of a hitherto unknown printed catalogue of the collection of the Public Library in Nassau, Bahamas published in 1862 has given library historians a glimpse at the type of books and periodicals available to residents of Nassau during the first decades after emancipation. An analysis of the library's collection may help to understand the role the library played in the cultural and intellectual life of the Colony and whether it had any influence on the cultural values of 19 th century Bahamian society.
\end{abstract}

\section{INTRODUCTION}

Research in Bahamian library history has been hindered by a lack of primary source material. Previous studies by Boultbee (1979) and Ballance and Bain (2000) reported that there was no evidence of a printed book catalogue, accession registers, board meeting minute books or library user records from the early years of the Nassau Public Library. However locating a printed book catalogue published in 1862, Catalogue of the Public Library, Nassau (Figure 1) has allowed scholars to have a fresh look at the history of the library and its collections.

This printed book catalogue, dating from the mid-19th century, from a small British colony in the Caribbean, serves as an interesting and valuable source to analyze the stock or inventory of books and periodicals that were available to library users at the time. An analysis of the library's collection can also help determine whether the library and its collection mirror cultural values of 19 th century Bahamian society.

This paper will review the origins of the Nassau Public Library and describe the arrangement of the printed book catalogue published in 1862, analyze the contents of the library collection and consider the influence the library and the nature of its collection might have had on early Victorian Bahamian reading interests and intellectual life.

\section{Origins of the Nassau Public Library}

The earliest known location of the Nassau Public Library and Reading Room was in a suite of rooms on the second floor of the

\footnotetext{
${ }^{1}$ Virginia C. F. Ballance, Nursing and Health Sciences Librarian, Libraries and Instructional Media Services, The College of The Bahamas, P.O. Box N-4912, Nassau, Bahamas.

Acknowledgments: The author is grateful to Dr. Barbara Curtis for her help in identifying the original owner of the book catalogue.

E-mail: vballance@cob.edu.bs

APA reference: Ballance, V. C. F. (2013). A new look at old books: The collection of Nassau Public Library in the mid-19th century. The International Journal of Bahamian Studies, 19, 31-45. https://doi.org/10.15362/ ijbs.v19i1.179
}

@ C.C.F. Ballance, 2013. Journal compilation @ The International Journal of Bahamian Studies, 2013 
Eastern Public Buildings on Rawson Square facing Bay Street, where today's House of Assembly is located. In her Letters from the Bahama Islands, 1823-24, Adele Hart writes, "The reading-room is in the public buildings, as well as the council chamber, and most of the offices for public business, which renders it a very disagreeable resort for ladies". She also noted "new books are seldom received here, excepting by some private individuals; and the merchant ships bring the periodical publications for the reading-room" (1948, p. 40). The Eastern Public Buildings were also the site of the Bank of the Bahamas and the Post Office. Located in the centre of the town of Nassau, the locale was bustling and busy, and no doubt too distracting for library and reading room patrons.

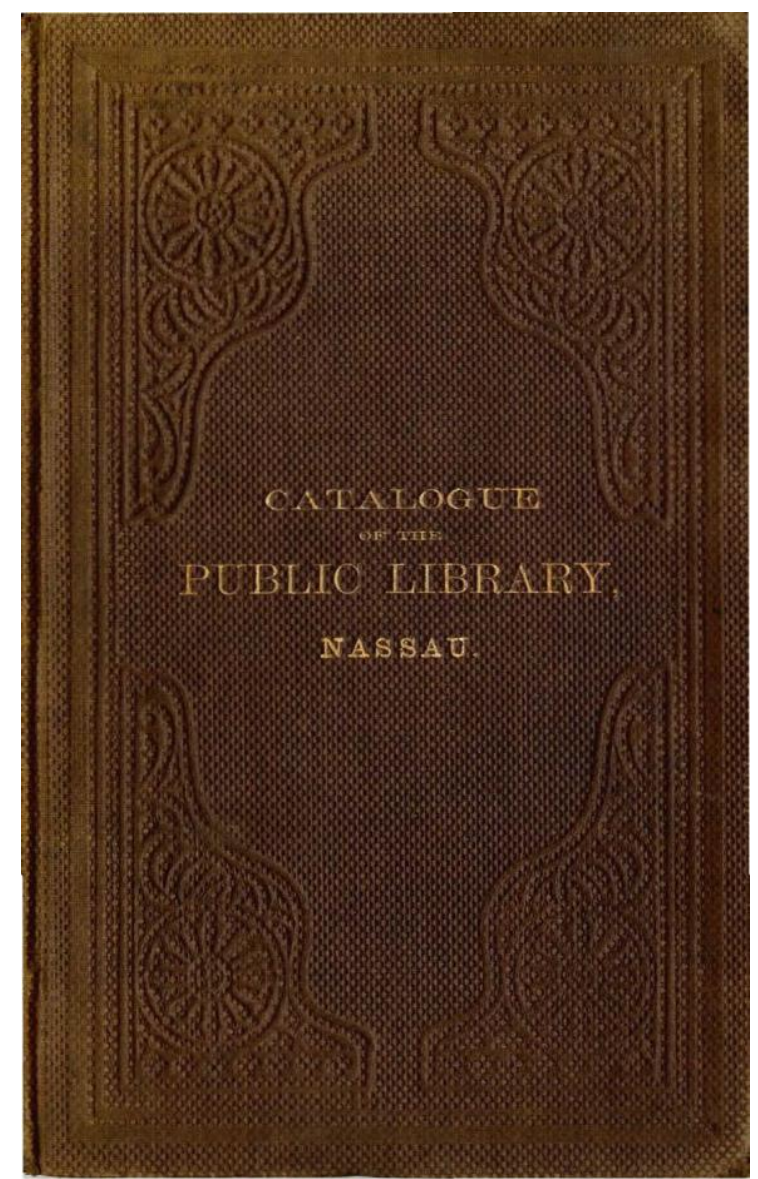

Figure 1. Cover of the Catalogue of the Public Library, Nassau. New York: L. Horatio Biglow, 1862
Mid-19th British century society had an obsession with knowledge, education and self-improvement, which they pursued through literary societies, reading groups, and educational institutes as well as public libraries. Among such groups in Britain was the Society for the Diffusion of Useful Knowledge (SDUK), established in 1826 by social and political reformers, Charles Knight and Henry Brougham. The SDUK's purpose was to impart "useful information to all classes of the community" (1829, p. 17), doing so primarily by producing cheap educational literature for the masses in the form of encyclopaedias, books, almanacs and journals. On this side of the Atlantic Ocean, in the United States, Mechanic's and Apprentice's Institutes, the Lyceum Movement and free public libraries were established to assist labouring and commercial classes with improving their education. In the new republic, social reformers believed that democratic ideals could be spread through education and literacy. They thought that if the masses were knowledgeable about current events, literature, and the sciences, the moral improvement of citizens would help combat crime, gambling and other vices that were prevalent at the time (Glynn, 1999, p. 351).

The Bahamas Society for the Diffusion of Useful Knowledge was formed in 1835 by the leading gentlemen of Nassau (Boromé, 1970, p. 215). During its short, two-year existence, the Bahamas Society presented lectures, conducted scientific experiments and collected scientific data in addition to holding meetings and publishing twenty issues of the Journal of the Bahamas Society for the Diffusion of Knowledge (Gillis, Byrne, \& Harrison, 1975, p. 4). In addition, the Society purchased scientific publications and laboratory equipment needed to further its objectives. Unfortunately, interest in the Society waned and its members decided to 
"... unite it with a 'Reading Society', but it is [then] called [the] "Nassau Library" (Bacot, 1869, p. 106). The Society was dissolved in 1837 and its equipment, natural history collections, journals and books were transferred to the "dressing room" ${ }^{2}$ of the public buildings. Although the reading room and library were an established part of the Eastern Public Buildings, it was only ten years later, in 1847, that the House of Assembly passed the Nassau Library Act to formally establish the Bahama Public Library and Museum (The Statute Law of the Bahamas, 1901, p. 73). The public library in Nassau was a constituted as a subscription library - members paid an annual fee to borrow books from the collection or to use the reading room, as opposed to it being a free public library wholly supported by taxes. Given the small population of the Bahamas at the time, the library could never have been entirely self-supporting, hence the House of Assembly provided funds to hire a full time librarian along with a small budget for the purchase of books and periodicals (Rawson, 1869, p. 27).

The 1847 Act "for establishing and supporting a Public Library and Museum in the town of Nassau" did however specifically state that the library's collection should include "a collection of books suitable for a working man's library, which shall be made available to the labouring classes of the community by a low scale of subscriptions adapted to their means" (Nassau Library Act, 1847, Sect. 5, para. 3). Such provisions were entirely in keeping with the ideals of the Bahamas SDUK to raise the general level of education of the population of the Colony and make

\footnotetext{
${ }^{2}$ Although the report in the Bahamas Argus newspaper refers to a "dressing room", this may in fact be a typographical error, and ought to have been recorded as "reading room", given the existence of a public reading room in the Public Buildings as early as 1823 .
}

education accessible to all members of society. The Trustees of the public library included the Governor, the Chief Justice and the Colonial Secretary (as ex-officio members) along with Rev. Maclure from the Presbyterian Kirk, and Messrs. Kirkwood and Duncombe, who were members of the Executive Council of the House of Assembly (Figure 2).

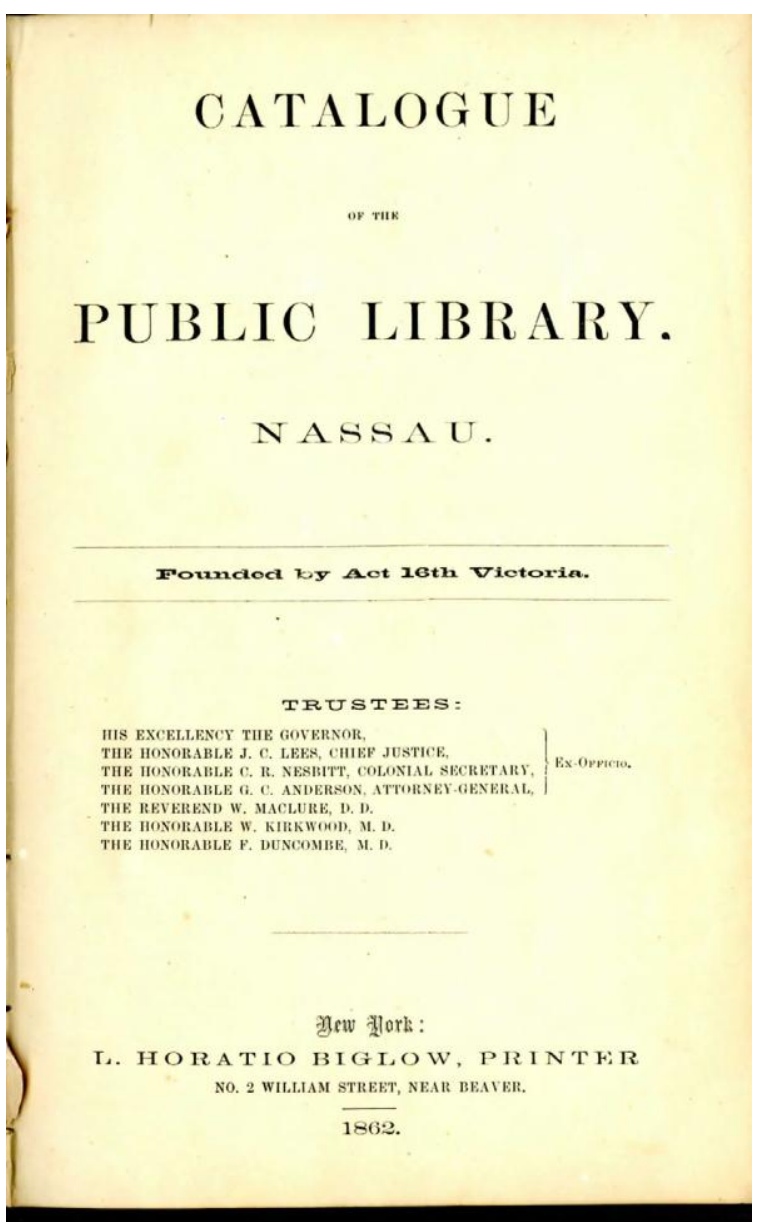

Figure 2. Title page of the Catalogue of the Public Library, Nassau. New York: L. Horatio Biglow, 1862. The Trustees were all leading gentlemen of Nassau society.

The Bahama Public Library and Museum remained in the reading room of the Eastern Public Buildings for 36 years, during which time the library gradually ran out of space to house its collections. It was not until 1873 that the Library moved across the square from the Public Buildings to the renovated "Old Prison". The public library has 
occupied the unusual landmark - the pink octagonal former prison - on Shirley Street since then. The House of Assembly passed an amendment to the Nassau Library Act in April 1874 changing the name of the institution to the Nassau Public Library, Reading Room, and Museum (The Statute Law of the Bahamas, 1901, p. 75). Fifteen years later, in 1892, legal materials that had been housed in the Public Library were moved to the upper Hall of the Centre Public Building of the courthouse in the public square thereby establishing the Colony's first law library (1901, p. 76).

\section{The Catalogue}

Prior to locating a copy of this catalogue, little qualitative information could be gathered on the library's collection. Reports of the Trustees of the Library to the House of Assembly were bland and statistical, merely enumerating the number of volumes or titles held by the library without any mention of the types of books in the collection or providing any other interesting details about the library.

Traveller's reports would sometimes comment on the library or its collection: "The public library does credit to Nassau both by its size and by the capital selection of its contents" (Bacot, 1869, p. 110), or, "There is an air of vitality as well as cheerfulness, about the clean, neat, quiet little town of Nassau, with its well-chosen library and literary institute" (Market scene, 1856 , p. 2). Therefore finding a copy of the printed book catalogue of the library has allowed historians a view of a library collection as it was in the mid-19th century, during a period of great social change and economic upheaval in a small backwater British colony.

The catalogue was published in New York in 1862, which was the second year of the Blockade during the American Civil War.
This period was one of tremendous wealth and economic activity for the Bahama Islands (Saunders, 1988). Three years earlier, in 1859, a regular postal service was established and the first Bahamian postage stamps were issued. In addition, Nassau began to be visited on a regular schedule by a steam ship, the S.S. Corsica, of the Cunard Line, out of New York. The first major hotel in Nassau, the Royal Victoria Hotel, opened in 1861, providing accommodations for tourists, invalids and others visiting the Bahama Islands from the United States and British North America for the winter season. The hotel also proved to be an attractive locale to the captains of blockade-running ships, their wives, Confederate agents, and war correspondents (Peters, 1945, p. 27). Travel diaries and accounts from later periods indicate that winter visitors made use of the library, so there is no doubt that visitors from an earlier period also availed themselves of the library located in the heart of the city within a short walking distance from the Royal Victoria Hotel.

In his diary of a family visit to Nassau in the winter of 1882, attorney William Gilbert Davies noted:

We stopped at the circulating library, a small round building in front of the hotel, and walked through it. We found quite a collection of stuffed birds, a very good assortment of books, and many of the English papers and magazines. We did not think it worthwhile to become subscribers, although the subscription price for visitors like ourselves is only two shillings sterling per month (Proctor, 1960, pp. 29-30).

The introduction to the catalogue sets out the rules for the public library and reading room as agreed to by members in September 1859 (Figures 3 and 4). It outlines membership dues, borrowing periods, sanctions and fines 
for various rule infractions as well as the hours of business. It indicated that record books were to be kept with the names of library users, as well as the books and periodicals borrowed. Unfortunately these records either no longer exist or have not yet been found in the Nassau Public Library archives. Access to such documents would open further lines of research and would give further insight into the composition of the membership and their reading habits, but it is quite probable that these records have long since been destroyed.

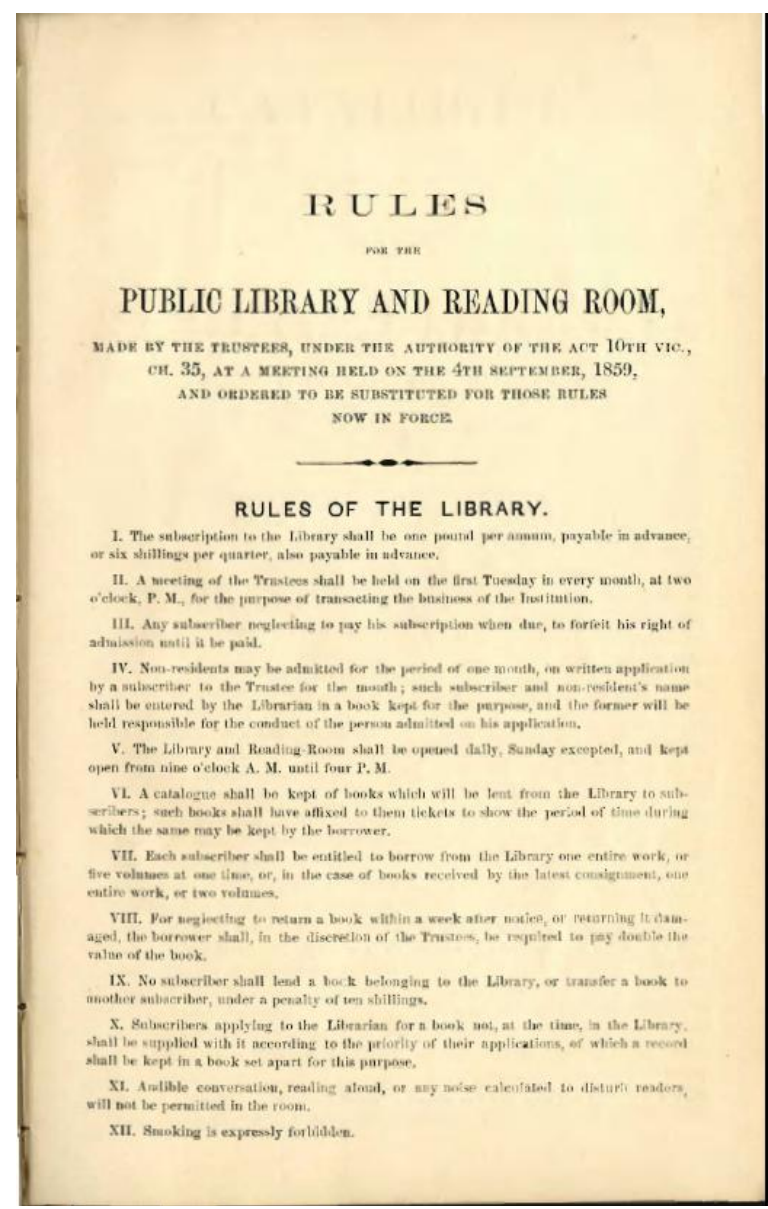

Figure 3. Rules of the Library. Catalogue of the Public Library, Nassau. New York: L. Horatio Biglow, 1862.

Other copies of this edition of the printed book catalogue have not been reported in library collections anywhere. This volume was found entirely by chance on a rare book dealer's online inventory.

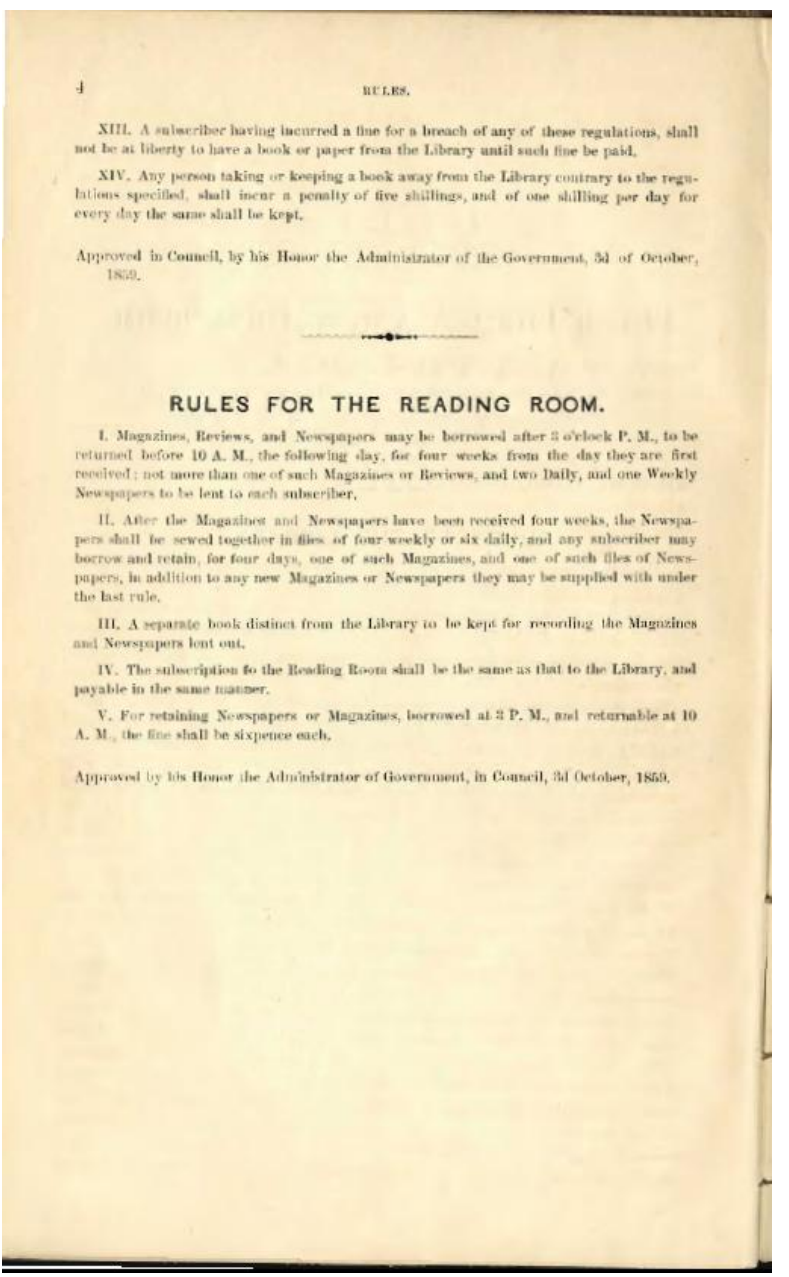

Figure 4. Rules for the Reading Room. Catalogue of the Public Library, Nassau. New York: L. Horatio Biglow, 1862.

The only evidence of the provenance of the catalogue is the presence of a previous owner's name written on the front flyleaf of the book. Written in pencil is the name Mary A. Curtis, Nassau, followed by a string of dates, 1865-66-67-69-71 (see Figure 5).

Although one cannot be completely certain, it is quite possible that the original owner of the books was Mary Ann Curtis, née Watkins, who was born in Rock Sound, Eleuthera in 1844. She met an Englishman, Thomas H. Curtis, either in the Bahamas or while she was working at a boarding house in the Florida frontier town of Lemon City (which later became Miami). They were married in Key West in 1873 and they lived 
there until her death in $1917 .^{3}$ She might have been among the many Bahamians who moved from the Out Islands to Nassau for employment during the boom years of the Blockade, and then onward to Florida in the late 1860 s and early 1870 s following the economic bust after the Blockade was lifted (Saunders, 2003, p. 29).

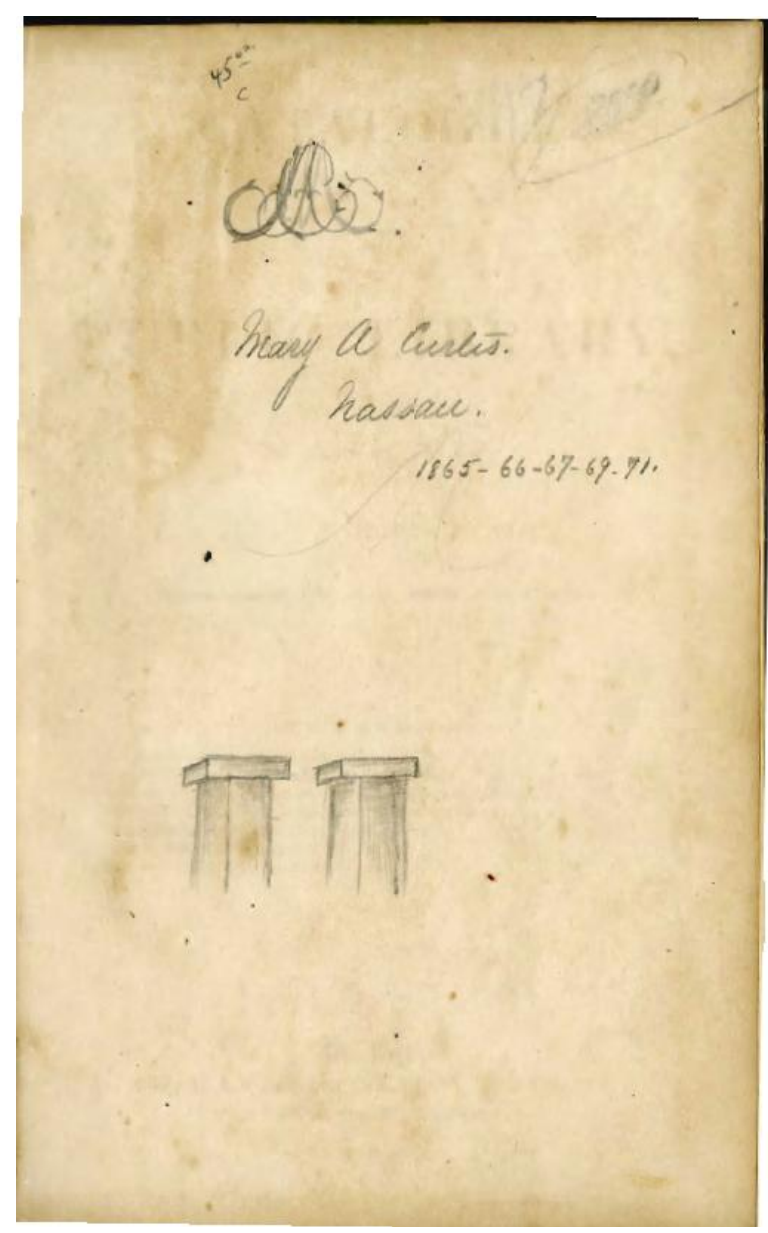

Figure 5. Flyleaf with previous owner's signature. Catalogue of the Public Library, Nassau. New York: L. Horatio Biglow, 1862.

In the 19th century, library attendants did not provide reference services for their patrons but merely procured and checked out books. Library users could not select books off the shelves for themselves but would choose titles from a printed book catalogue

\footnotetext{
${ }^{3}$ A photograph of her headstone is on this site: http://www.findagrave.com/cgibin/fg.cgi?page =gr\&GSIn=Curtis\&GSiman=1\&GScnty $=359 \&$ GRid $=33545338 \&$
}

and the library attendant would retrieve the books (Bowman, 2006, p. 67). This was because library collections were not classified by subject (i.e. given call numbers), but the books were given a consecutive number and simply placed on the shelves in order of acquisition. It was not until the early 20th century that the card catalogue and classified collections became common features in public libraries. A printed book catalogue was necessary for library attendants and library users to know which titles were in the collection.

As was the case with most printed book catalogues of the period, the catalogue of the Nassau Public Library was a very simple "dictionary catalogue", in other words it was organized like a dictionary, in alphabetical order. Every title in the catalogue was listed by author or title, in alphabetical order, and, each letter of the alphabet started on a new page. The custom was to limit each book to one entry in the catalogue (Ranz, 1964, p. 24). Words in the book's title would frequently be re-ordered so that key words would appear at the start of a phrase, creating a semblance of subject access to the collection. Form headings, or words such as encyclopaedia, dictionary, or essays, were used to group together similar titles. Though unsophisticated, and far from thorough, it did elevate the catalogue from a mere alphabetical author or title inventory to a somewhat useful index to the collection. Each volume in the library's collection was assigned a consecutive accession number, not a classification number as is customary today, making it possible to determine the number of volumes per title and total number of volumes in the collection. The publishers bound in blank interleaving pages between each letter of the alphabet, presumably to allow the owner of the catalogue to make notations of new titles. The 1862 edition of the Nassau Public 
Library catalogue was similar to catalogues produced at the time by many public libraries in the United States, Canada and Great Britain. Elsewhere in the Caribbean, printed book catalogues were produced in Jamaica (Institute of Jamaica, 1888) and Barbados (Walcott, 1879).

It is inevitable that errors appear in the compiling of a work like this catalogue. For example, there are numerous entries not in alphabetical order and some oddities, such as "Faust's Goethe". The catalogue also contained countless other perplexing typographical errors, such as Jewitt for Lewin and United Kingdom for vegetable kingdom; or using the wrong variant spelling of a surname, such as Stuart for Stewart and Reed for Reid. (Figure 6).

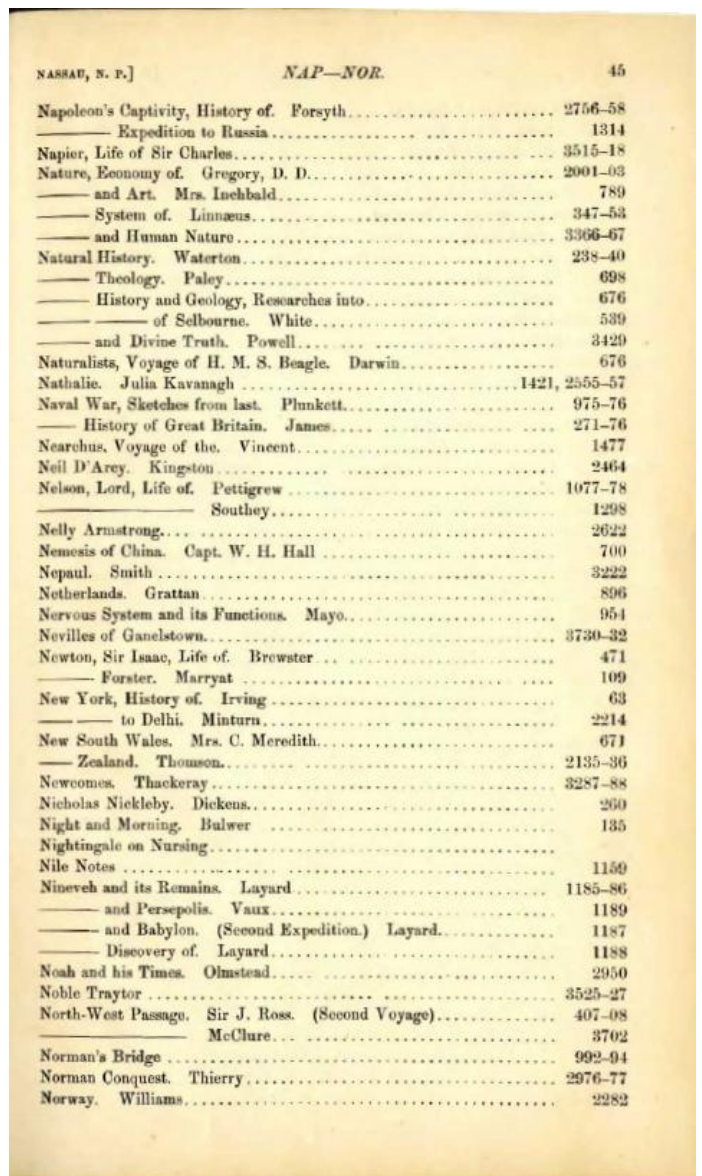

Figure 6. Example of alphabetical arrangement, errors and rough subject access. Catalogue of the Public Library, Nassau. New York: L. Horatio Biglow, 1862.
The Nassau Public Library issued a second edition of the catalogue in 1870, published in London by William Clowes and Sons, perhaps to correct the errors and discrepancies of the 1862 edition. It may include many more titles and perhaps more subject entries as the second edition has 191 pages, more than double the number of pages in the 1862 edition. ${ }^{4}$

Among the advantages of a printed book catalogue was that readers could purchase a copy to use at home to keep track of which books they had read or would like to read. The printed book catalogue itself was also used by the library as a means of promotion, "advertizing the scope and content of the library collection, hoping to attract contributions of money and books" (Taylor, 1976, p. 348). Library book catalogues were even critically reviewed in the professional press of the day (Bowman, 2006, p. 83). However, producing a printed book catalogue was an expensive undertaking for a library and occupied much of the librarian's time (Ranz, 1964, p. 23). In addition, after compiling, revising, printing and proofreading, the catalogue would be out of date almost as soon as it was published, as the library would surely have acquired new books in the interim.

Nevertheless in the 1860s, the Bahamian Colonial government provided the Nassau Public Library with the funds to purchase new book stock, to publish a printed book catalogue and to underwrite the fine bookbinding of completed volumes of magazines and journals. Several titles listed in the 1862 catalogue can still be found on the shelves at the Nassau Public Library, distinguished by their bookplates and by their fine leather binding and gold embossing. Unfortunately, many books

\footnotetext{
${ }^{4}$ Two libraries report holding the second edition of the catalogue according to the WorldCat ${ }^{\mathrm{TM}}$ database.
} 
from the 19th century have suffered damage from not being housed in a climatecontrolled environment: from mold, mildew, or insect infestation.

\section{Analysis of the Collection}

Annual reports of the Bahamian Colonial government from the second half of the 19th century note that the library collection grew from 1,550 volumes in 1850 to 3,650 volumes in 1858 and to over 5,000 volumes in 1873. The catalogue of 1862 included about 1,930 titles and over 4,000 volumes, which more or less corroborates with statistics published the Library's annual reports found in the Votes of the Honourable House of Assembly.

It was during the 19th century that the Encyclopaedia Britannica first appeared, along with countless other "cyclopaedias" and compendia of knowledge. The Nassau Public Library collection included numerous reference books, such as Encyclopaedia Americana, Encyclopaedia Britannica, and the Cyclopaedia of Political Knowledge, to name a few examples of the twenty listed in the catalogue, as well as gazetteers, atlases, and directories. There was also a good selection of dictionaries, such as Johnson's, Webster's, Worchester's and Roget's dictionaries and specialized dictionaries for art, languages, geography, history, and the classics.

\section{Serialized or Periodical Literature}

In the early 19th century, periodicals and newspapers were the most widely read forms of literature, whether published daily, biweekly, tri-weekly or monthly, largely because they were cheap, easy to produce and distribute given advances in printing technology, paper production and transportation. Many works of fiction appeared first in serialized form before publication as a monograph.

The Nassau Public Library and Reading
Room subscribed to a number of newspapers, magazines and reviews. Guidebooks and traveler's accounts as well as official reports indicated that the Reading Room was "supplied with the leading English newspapers, magazines \&c." (Almanack, 1878, p. 74), but examples of specific titles were never given. Titles of magazines, journals and periodicals were listed in the printed catalogue, making it possible to determine that readers were indeed supplied with the most popular highbrow periodicals published in the 19th century. There were over 40 periodical titles listed in the catalogue and they appealed to literary and scholarly interests as well as popular topics. Included in the collection were: Ainsworth's (literary), Harper's (general political, cultural), Fisher's Colonial (commercial), Gentleman's Magazine (miscellaneous information, obituaries, parliamentary notices, etc.), Mechanic's (technology), Illustrated London News (current events), and Blackwood's Edinburgh magazine (poetry, imaginative literature, essays, etc.). Lacking however are the popular story papers such as Saturday Journal or Golden Hours and many of the dime novel weeklies such as those published by Munro, Frank Starr, Beadle and Dewitt.

What is noteworthy however is the complete lack of women's magazines. In Britain at the time, some public libraries had designated reading rooms for women, and supplied them with a wide array of magazines and periodicals published especially for the female reader (Baggs, 2005). Among the periodical titles found in the Nassau Public Library collection are a few that would have been found in the ladies reading rooms in Britain in the mid-19th century, such as the Illustrated London News and Chambers' Journal. Not found were any of the popular women's newspapers and periodicals such as The Englishwoman's 
Domestic Magazine, The Ladies' Companion, nor any of the fashion, religious and current events magazines published for the female audience or titles related to women's professions (Baggs, 2005, p. 298; Kelman, 2003).

\section{Monographs}

In the 19th century, newly released British novels and other popular books would be republished under an American imprint within months of appearing in England. Popular novels appeared in new editions year after year, largely because of the rapid increases in mass literacy and the public's voracious appetite for reading materials. Of the 1,900 or more monographic titles listed in the catalogue, bibliographic records were found for $86 \%$ of the titles in the WorldCat ${ }^{\mathrm{TM}}$ database. Without access to the physical books, it was difficult to ascertain whether the Nassau Public Library owned the British or American edition of a particular work, or, if the title was a reprint, exactly which edition would have been held. Of the 200 titles for which bibliographic information could not be found (often because insufficient information appeared in the catalogue) it is possible that many were works of fiction or children's books. Nevertheless, with the cut-off date for the catalogue sometime before 1862, the majority of the titles for which bibliographic information could be found were published between 1840 and 1862, with a peak in 1857 or 1858. It is quite possible that it took two years to have the catalogue printed in the United States and shipped back to the Bahamas.

The preponderance of titles in the collection fit several general categories, the largest being fiction and literature, followed by history and travel, and finally, in much smaller numbers, religion and psychology. Although most libraries of the era catered to adults, the Nassau Public Library collection included a few books for children. While some of these could be deemed educational or morally uplifting fiction, such as Thomas Day's Sandford and Merton (1809) and Inchbald's A Simple Story (1849) and Nature and Art (1849), the library also held many illustrated books and fairy tales, such as those by Andersen and Perrault.

\section{Non-fiction}

The age of discovery and exploration of the late 18th and early 19th century is clearly reflected in the subjects of the books in the collection. Travelogues, guidebooks and histories of many parts of the world - the United States, Canada, the Arctic, England, all parts of Africa, Asia, the Middle East, the Pacific, Australia - were well represented. At the time, travel was a dangerous pasttime; therefore armchair travelers could vicariously enjoy adventures, descriptions and the history of far-away places through reading. Among the hundreds of choices in the Nassau Public Library were the famous accounts of explorers James Cook and Alexander Mackenzie, scientific explorers Charles Darwin and Alexander de Humboldt, as well as half a dozen contemporary accounts of the Crimean War.

Books describing scientific discoveries in the natural, physical and medical sciences were available to Nassau Public Library's users. With the development of better microscopes in the 19th century there were many discoveries made in the sciences which resulted in the "new" sciences of chemistry, biology and archaeology. There were 10 books about chemistry, 12 books on natural sciences and biology and four titles on palaeontology and archaeology. And, there were five titles about the microscope. In the physical sciences, discoveries in the early part of the 19th century included astronomy and geology and the library collection included 16 and 12 titles, respectively. The collection included the 
Principles of Geology (1830) by Charles Lyell, in which the theory that the world is actually several hundred million years old is offered for the first time.

One of the more interesting (and intriguing) titles in the library collection was Wonderful Adventures of Mrs. Seacole in Many Lands (1857) an account by a Jamaican Creole "doctoress", Mary Seacole, who nursed soldiers injured in the Crimean War. Mary Seacole had visited the Bahamas in about 1834. The library held the other classic of nursing literature, Florence Nightingale's Notes on Nursing, What it is and What it is not (1860), as well as about 15 other medical-related books: general works on surgery, gynecology, ophthalmology, hygiene and pathology. Given the pandemics of cholera in the early part of the 19th century, it isn't surprising that the library had Observations on the Nature and Treatment of the Asiatic Cholera by Stevens, published in 1853.

There were over 100 biographies in the collection: collective works, such as Arago's Biographies of Distinguished Scientific Men (1857) and Thackeray's The English Humourists of the Eighteenth Century (1854) and individual biographies, such as Mrs. Gaskell's Life of Charlotte Bronte, (1854) and Boswell's Life of Samuel Johnson (1826).

Titles of local interest, or what today would be referred to as Bahamiana, included The Statute Law of the Bahamas (1826), the Bahama Herald, Mark Catesby's The Natural History of Carolina, Florida, and the Bahama Islands (1771) and the Memoirs of Peter Henry Bruce, esq., A Military Officer, in the Services of Prussia, Russia, and Great Britain. (1782). Today the works of Bruce, the military engineer who built Forts Montague and Nassau (the site of the present-day British Colonial Hotel) and
Catesby are extremely rare and very valuable books. Widening the local interest scope to include the West Indies, a further 20 titles were available, many being travel accounts to various countries in Central America, other Caribbean islands, (particularly Jamaica and Cuba), and books about slavery and its abolition. Finally, a title that would have had particular interest and application for residents of the Bahamas was Ryder's Practical Rules for Determining the Course to be Steered to Escape from a Hurricane (1851).

\section{Fiction}

Following newspapers and periodicals, the most popular reading matter during the period was fiction. In 1800 fiction comprised less than $2 \%$ of annual book production in the United States but by 1835 it had increased to $15 \%$ (Kaser, 1980, p. 64). By 1820 the percentage of fiction in the book stock of libraries had risen to well over $50 \%$ in American circulating libraries, which, as Kaser (1980) notes, were operated as businesses, renting books to library members (p. 67). A similar trend seems to appear in the collection of the Nassau Public Library as close to $40 \%$ of the collection included books classed as fiction or works of literature. Until the late 1800 s, most works of fiction appeared in three volumes and were commonly known as "triple deckers". Though expensive to purchase by the individual, they were destined for the circulating and subscription library market presumably because each volume would circulate separately and thereby increase profits to the library.

The European novel came of age in the early 1800 s with the publication of Sir Walter Scott's Waverley Novels (1829); all 48 volumes were in the Nassau Public Library. The collection also included the works of major British novelists and poets of the time such as Charles Dickens, Edward Bulwer- 
Lytton, the Bronte Sisters (these appear in the catalogue under their pseudonyms Currer and Acton Bell), Thomas Carlyle, William Makepeace Thackeray, Lord Tennyson, Frederick Marryat, Mrs. Gaskell, George Eliot, Anthony Trollope, Charles Lever and Samuel Lover.

Comparing titles in the catalogue to Allingham's list of best selling and significant novels of the early Victoria era, 1837-1861 (2008), it appears that for most years the Nassau Public Library had over half of the titles on the list. However, there were years for which the library did not have even one title that appeared on the list. While the major authors of the late 18th and first half of the 19th century are represented, curiously absent are the novels of Jane Austen, Wilkie Collins, George Meredith, the best-known novels of Charles Kingsley and all but one of William Harrison Ainsworth's novels.

Although slavery had been abolished in the Bahamas in 1834, it continued in the United States until the 1860s. Harriet Beecher Stowe's novel Uncle Tom's Cabin (1852), and her reply to the anti-abolitionists, $A$ Key to Uncle Tom's Cabin (1853), were in the library collection, along with her follow-up novel to Uncle Tom's Cabin, Dred: A Tale of the Great Dismal Swamp (1856). It is perhaps not unusual to find Beecher Stowe's masterpieces are in the Nassau library collection because Uncle Tom's Cabin was the best-selling American novel of the 19th century and the most persuasive and controversial anti-slavery tracts ever published. Other well-known anti-slavery works of prose fiction, such as those listed on the Antislavery Literature Project website (http://antislavery.eserver.org.prose) did not appear to be in the collection.

\section{The Role of the Library in mid-19th Century Nassau's Cultural Life}

Nassau society in the mid-19th century was a microcosm of Victorian society in Britain, sharing its mores and customs, zest for knowledge and understanding of the world. However, the population of the Bahamas was divided by race and class: society was dominated by a small white merchant class, in the middle, a small coloured and black educated class and at the bottom, the labouring class of which the majority were black (Saunders, 1989). Without access to historical records of library subscribers or members, it is difficult to know exactly who frequented the library and reading room.

Given the prevailing social and economic divisions of Nassau society, it would be reasonable to presume that the majority of members would have come from the white merchant class. But, there is no way to be sure of the extent to which educated middleclass coloured and blacks might also have been members or subscribers of the library and reading room given the postemancipation changes in the composition of Bahamian society (Saunders, 2003).

In the 1850s Thomas M. Matthews, a coloured middle-class lawyer, was a member of the Board of Trustees of the library (Themistocleous, 2001, p. 14). Among the educated classes of society, regardless of their race, access to the library and reading rooms afforded a venue where they could mix socially. It is conceivable that the postemancipation period Governors Rawson and Gregory, along with their Colonial Secretaries, such as C. R. Nesbitt, would have encouraged the educated middle-class black and coloured elites to frequent the public reading room and library and to attend the lectures and events offered by the Bahama Institute.

Although the Nassau Library Act had 
specified that the collections of the Library should cater to the working man or labouring classes of society and that "a low scale of subscriptions adapted to their means" (The Statute Law of the Bahamas, 1901, p. 73), there is no evidence in the 1862 Rules for the Public Library and Reading Room that lower subscription fees were an option. Subscriptions were one pound annually (or 6 shillings per quarter), a sum that only the more well-off members of society would have been able to afford. ${ }^{5}$

Victorian society's penchant for forming societies and associations, mainly with an intellectual or self-improving objective, was also evident in the Bahamas. The public library and reading room were one of several institutions that helped shape the cultural life of the Colony during the Victorian era.

In 1848 the Bahamas Literary Society was formed and throughout the 1850 s and $1860 \mathrm{~s}$ several communities outside of New Providence petitioned the Governor for funds to establish public libraries. ${ }^{6}$ The Bahama Institute, a society for advancing literature and science, was founded in 1854 (Votes of the Honourable House of Assembly, 1854). Its first president was Chief Justice J. C. Lees, who was also the Chairman of the Board of Trustees of the public library and had a great interest in agriculture and botany. Throughout the period of its existence the Bahama Institute sponsored lectures on historical, scientific and other topics of contemporary interest, such as Ancient Greece and the atmosphere. On the Tercentenary of Shakespeare's birth, the Bahama Institute sponsored a series of evenings of dramatic readings of his plays

\footnotetext{
${ }^{5}$ The Librarian of the Public Library was paid $£ 50$ per year: in 1862 a membership fee of $£ 1$ would have been a considerable financial outlay for someone with a modest income.

6 Libraries were established in Dunmore Town, Harbour Island, 1854; Mathew Town, Inagua, 1855; and New Plymouth, Abaco, 1862.
}

and sonnets to raise funds to purchase a bust of The Bard for the Public Library. The bust continues to be prominently displayed at the Nassau Public Library. The Bahama Institute provided entertainment for tourists as well as the local population. While visiting Nassau on a tour of the tropics, American writer John Milton Mackie noted "instead of the opera, there are concerts and lectures once a fortnight at the Bahama Institute: (1864, p. 218). These evening events were well attended and students from various schools were invited to attend.

At its August 1863 meeting the Institute's members decided to suspend events as they had no time to organize lectures and concerts owing to the many "social, domestic and commercial" distractions during the American Civil War and Blockade (Votes of the Honourable House of Assembly, 1866, p. 73). The Bahama Institute resumed its meetings and soirées late in 1865 but it proved difficult to sustain its activities. And, like its predecessor, the Bahamas Society for the Diffusion of Useful Knowledge, the Bahama Institute donated its collections of scientific apparatus and books to the Nassau Public Library and the Act establishing the Bahama Institute was formally repealed in April 1899.

Besides borrowing books from the Public Library, Nassau residents could purchase books and magazines from the News Depot at Schrimshaw \& Co., located opposite the New Methodist Church on Frederick Street. Advertisements in the Nassau Guardian listed many of the same titles and books by the same authors that were available in the library. They also sold several women's magazines, such as Leslie's Lady's Magazine and Goday's Lady's Book, which were not available in the library.

The library not only offered entertainment but also opportunities for education and self- 
improvement, and many of the books available might have had some influence on their member's opinions and outlook. At its founding, the core of the Nassau Public Library collection came from the publications acquired by the Bahamas branch of the Society for the Diffusion of Useful Knowledge. The publications of the SDUK and its founders were progressive works intended to educate and enlighten their readers. Among a great number of religious books included many works about ethics, morality and the proper conduct of life in addition to commentaries and interpretations of biblical texts and collections of sermons. Books on politics, economics, and social reform were in the collection, as were anti-slavery tracts and many works of fiction with a moral message.

In the years following the Blockade, existence of such associations as the Bahama Institute, the public library, the Bahamas Literary Society, and the establishment of schools throughout the Colony (although they were poorly funded) reflected steps taken by the leaders of Nassau society to improve literacy and influence local intellectual and cultural values (Craton \& Saunders, 1998, p. 25-27). Chief Justice J. C. Lees and Reverend W. Maclure from the Presbyterian Kirk, both Trustees of the Library and members of the Bahama Institute, had a deep interest in the cause of public education and the promotion of cultural and intellectual pursuits. The influence of these institutions and with the support of Governors Gregory and Rawson throughout the boom years of the Blockade may have encouraged members of the mercantile class to support public institutions such as the Public Library as well as to mix socially on the committees of charities and public institutions. Governor Rawson noted in his Annual Report for 1864 that "Nassau at least is not wanting in several of those institutions which serve to marks its social and educational standard" (1866, p. 64).

\section{CONCLUSIONS}

Subscribers of the Public Library in Nassau in the mid-19th century were supplied with many of the best magazines, periodical reviews and books published at the time. The selection of periodicals included many of the more intellectual titles available but few of the popular weeklies and no women's magazines. Readers had access to the latest works of fiction, in particular, but were also able to read a wide variety of traveler's accounts from all corners of the world, interesting biographies and histories as well as religious and science books, many of which are now regarded as classics.

The first edition of the printed book catalogue was published in the midst of the American Civil War and the Blockade running years, and during the first decades after slavery was abolished in the Colony. The great number of errors found in the catalogue may reflect the haste with which the library had to use funds that were easily accessible during this period of excess and unfettered economic activity.

Despite Nassau's residents living in a relatively remote, backwater, Colony, the library was able to provide a reasonably interesting collection of reading materials on topics of contemporary interest. Although libraries and education were chronically underfunded, the grants and support that the library received in the mid-19th century reflected efforts of the Governors and church and civic leaders to elevate the level of education and interest in the outside world among all classes of Bahamian society. 


\section{REFERENCES}

Allingham, P. V. (2008, July 28). Significant and best-selling Victorian novels, 18371861 , by year of volume of publication. Retrieved from http://www.victorianweb.org/authors/dicke ns/pva/pva90.html

An almanack for 1879, with a guide to the Bahamas, Nassau directory \&c. (1879). Nassau: E. C. Moseley.

Bacot, J. T. W. (1869). The Bahamas: A sketch. London, England: Longmans, Green, Reader and Dyer.

Baggs, C. (2005). "In the separate reading room for ladies are provided those publications specially interesting to them": Ladies' reading rooms and British public libraries 1850-1914. Victorian Periodicals Review, 38, 280-306. doi:10.1353/vpr.2005.0028

Bahamas Legislature. House of Assembly. (1854, 1866). Votes of the Honourable House of Assembly of the Bahama Islands. Nassau: Bahamas: J. Eve.

Bahamas Public Library. (1862). Catalogue of the public library, Nassau. New York, NY: L. Horatio Biglow.

Ballance, V., \& Bain, E. (2000). Bahamian public libraries: An overview. Nassau, Bahamas: Bahamas Library Publications. Available at http://ufdc.ufl.edu/AA00007599/00001

Boromé, J. A. (1970). Origin and growth of the public libraries of Dominica. The Journal of Library History, 5, 200-236.

Boultbee, P. (1979). The Nassau Public Library: A Victorian interlude. Journal of the Bahamas Historical Society, 1, 3-8.

Bowman, J. H. (2006). The decline of the printed catalogue in Britain. Library History, 22, 67-99. doi:10.1179/174581606X117652
Craton, M., \& Saunders, G. (1998). Islanders in the stream: A history of the Bahamian people. Volume two: from the ending of slavery to the twenty-first century. Athens: University of Georgia Press.

Gillis, W. T., Byrne, R., \& Harrison, W. (1975). Bibliography of the natural history of the Bahama Islands. Washington, D.C.: Smithsonian Institution. Retrieved from http://www.dloc.com/AA00005050/00001

Glynn, T. (1999). Books for a reformed republic: The Apprentices' Library of New York City, 1820-1865. Libraries \& Culture, 34, 347-372.

Hart, A., \& Kent, R. (1948). Letters from the Bahama Islands: Written in 1823-24. London, England: J. Culmer.

Institute of Jamaica. (1888). Catalogue of works added to the public library, Jamaica Institute, 1887-88. Kingston, Jamaica: The Institute.

Kaser, D. (1980). A book for a sixpence: The circulating library in America. Pittsburg, PA: Beta Phi Mu.

Kelman, K. (2003). "Self culture": The educative reading pursuits of the ladies of Edinburgh 1865-1885. Victorian Periodicals Review, 36, 59-77.

Mackie, J. M. (1864). From Cape Cod to Dixie and the tropics. New York: G. P. Putman. Retrieved from Google Books.

"Market scene". (1856, February 27). Bahamas Herald, p. 2.

Nassau Library Act of 1847, Ch. 49. Retrieved from http://laws.bahamas.gov.bs/cms/images/LE GISLATION/PRINCIPAL/1847/18470035/NassauLibraryAct_1.pdf 
Peters, T. (1945). Blockade running in the Bahamas during the Civil War. Tequesta, 5, 16-29. Retrieved from http://digitalcollections.fiu.edu/tequesta/fil es/1945/45_1_02.pdf

Proctor, S. (1960). A trip to Nassau, 1882: A travel diary. Caribbean Quarterly, 6, 2644.

Ranz, J. (1964). The printed book catalogue in American libraries, 1723-1900.

Chicago, IL: American Library Association.

Rawson, R. W. (1866). Report on the Bahamas for the year 1864. London, England: Eyre and Spottiswoode. Retrieved from http://hdl.handle.net /2027/yale.39002005619359

Saunders, G. (1988). The Blockade running era in the Bahamas: Blessing or curse? Journal of the Bahamas Historical Society, 19, 14-18.

Saunders, G. (1989). Life in New Providence in the early nineteenth century. Journal of the Bahamas Historical Society, 20, 16-21.

Saunders, G. (2003). Bahamian society after emancipation. (Rev. ed.). Kingston, Jamaica: Ian Randle.
Society for the Diffusion of Useful Knowledge. (1829). Reports and prospectus. London, England: Baldwin and Craddock, C. Knight. Retrieved from http://www.jstor.org/stable/60211129

Taylor, B. W. (1976). Bibliographic control and guides to historical sources, part 1: American law library book catalogs. Law Library Journal, 69, 347-368.

The Statute Law of the Bahamas: Comprising all Acts of the General Assembly of the Bahama Islands in force to 62 Victoria, Chapter 33, inclusive. (1901). London, England: Eyre and Spottiswoode.

Retrieved from http://www.archive.org/details/cu3192401 7501465

Themistocleous, R. (2001). Coloured members of the Bahamian House of Assembly in the nineteenth century. College of the Bahamas Research Journal, 10, 10-22. Retrieved from http://journals.sfu.ca/cob/index.php/files/ar ticle/view/36/64

Walcott, J. E. (1879). Catalogue of the books in the public library of Barbados. London, England: Waterlow. 